\title{
UK scientists test liposome gene therapy technique
}

London. A group of British scientists and physicians last week began the world's first human trials of a gene therapy technique that uses liposomes rather than viruses to transfer fragments of DNA, in this case a working version of the gene whose dysfunction causes cystic fibrosis.

The news is all the more pertinent because attempts in the United States to use an attenuated adenovirus for gene therapy of cystic fibrosis $(\mathrm{CF})$ patients are running into unexpected problems. In particular, a trial at the National Institutes of Health's $\mathrm{Na}$ tional Heart, Lung and Blood Institute (NHLBI) has been stopped after a patient developed a lung inflammation.

Researchers are also reporting that although adenoviruses are a highly efficient way of introducing genes on their first application, the level of gene expression sometimes drops off sharply in subsequent applications.

Consequently, researchers are watching the British trial closely, because it will provide the first comparison of the safety and efficacy of both approaches. Given the vast potential market of a drug for $\mathrm{CF}$, one leading US business magazine has already dubbed the competition between the two approaches as the "\$600 million horse race".

Ever since the $\mathrm{CF}$ gene was identified and isolated in 1989, scientists have concentrated on developing a gene replacement technique to prevent the damage that occurs when the dysfunctioning gene blocks transport of water and salt across cell membranes in the lung wall.

Earlier this year, the NIH approved the first clinical trials of gene therapy for cystic fibrosis. Ron Crystal at NHLBI is carrying out the trial, which uses adenoviruses as vectors, whose pathogenicity has been eliminated, because they spread rapidly in the lungs.

In the British trials the genes are wrapped in liposomes. These fuse with the cell membrane and discharge the genes into the cell. The technique works in mice bred with a defective $\mathrm{CF}$ gene. "We are now moving from the concept to the clinical trials", says David Porteous of the Medical Research Council's (MRC) Human Genetics Unit in Edinburgh, one of the collaborators in the British trials.

Duncan Geddes, clinical director of respiratory medicine at the Royal Brompton Hospital in London, is supervising the trial which is being carried out at the hospital's National Heart and Lung Institute; the MRC and the Cystic Fibrosis Trust are funding the trial.

In the first stage, the liposomes will be administered in a nasal spray to nine young male volunteers to test if the technique is safe and effective. If it is, then the spray will be administered directly to the lungs of patients.

The British scientists say that liposomes are simpler and potentially safer than adenoviruses. "We thought that using fatmediated entry into cells would be a milder way of doing things", says Bob Williamson, professor of biochemistry at St Mary's Hospital Medical School in London; the school has studied the genetic basis of CF since the mid-1980s.

Groups in the United States are planning similar trials, following the successful introduction of functioning CF genes into rhesus monkeys using liposomes. "We hope liposomes will prove sufficiently effective and complication-free to allow them to be

\section{Human Frontiers Programme wins art prize}

Tokyo. Japanese researchers are pleased, but puzzled, by news that the French maker of champagnes, perfumes and designer bags, Möet Hennessy-Louis Vuitton (LVMH), is to award an art prize to the Japanese-inspired Human Frontiers Science Programme (HSFP) - for its "remarkable vision in promoting international research on the brain and biological functions."

Two of the main architects of HFSP, Akiyoshi Wada (Sagami Chemical Research Centre) and Masao Ito (Riken), will be presented with the "Trophée d'Honneur de Science pour l'Art" on 14 September in Tokyo.

Japan is pleased because its sees the award by a French company as a vindication of Wado and Ito's position in their public row last year with Sir James Gowan, former director of HSFP, over the direction of the programme (see Nature 328, 527; 1992).

But Japanese researchers are still puzzled as to what a "Science pour l'Art" prize is. The explanation is that besides this oneoff tribute to HFSP, LVMH every year awards two FF 100,000 prizes to individual scientists whose work has had a "direct or indirect impact on artistic creation, aesthetics, and industry": this year's winners are Sir Samuel Edwards, a theoretical physicist at the University of Cambridge for his work on polymers, and Wolfgang Helfrich, of Freie University in Berlin, for his invention of liquid crystal displays. But LVMH concedes that the links between science and art are usually tenuous. David Swinbanks applied for the lifetime of a patient", says Robert J. Debs of the University of California, San Francisco.

Until the results of these first British and US trials of liposomes are known, there is no guarantee that they will not run into the same sort of problems as those now affecting trials of adenovirus vectors.

But commercial interest in the outcome of both types of trials is already considerable: there are 20,000 cystic fibrosis patients in the United States alone and almost 7,000 in Britain; many of them might be prepared to pay up to $\$ 50,000$ a year for a treatment that would avoid the need for gruelling and time-consuming forms of treatment. Genentech has invested \$17 million in the Maryland-based company Genvec, which Crystal set up to support his experiments. Another company, Megabios, is supporting liposome work.

British companies have shown less interest. Several big pharmaceutical companies are interested in principle, but none has yet backed clinical trials. Commercial interest has so far been restricted to the potential market for CF screening kits. David Dickson

\section{Industry funding of UK universitites static}

London. Despite government pressure on British universities to concentrate more on wealth creation, the proportion of research funded by industry has remained static since the mid-1980s.

According to figures released last week by the Universities' Statistical Record, funding by industry increased from $£ 78$ million in the academic year $1987-88$ to $£ 120$ million in 1991-92. But universities increased their total research income over the same period from $£ 708$ million to $£ 1,137$ million, leaving industry's share unchanged at around 11 per cent.

In contrast, charities doubled their funding of university research over the same period, and increased their share of the total from 15.4 to 19.2 per cent. The European Commission also increasingly supports research in British universities: such funding grew by 20 per cent between 1990-91 and 1991-92 alone, compared with a mere 2 per cent increase in research council funding over the same period.

Oxford and Cambridge reinforced their positions at the top of the total research income league, with $£ 63.6$ million and $£ 48.5$ million respectively: although the University of London's total of $£ 314$ million dwarfs both figures, this is not broken down by individual colleges.

Government support for university research - including income from the research councils and individual government departments - fell from 52 to 45 per cent of total university research between 1988-87 and 1991-92. 